\title{
ASSESSMENT OF COASTAL RECEPTORS' EXPOSURE VULNERABILITY TO FLOOD HAZARD ALONG VARNA REGIONAL COAST
}

\author{
Nataliya Andreeva ${ }^{1}$, Nikolay Valchev ${ }^{1}$, Bogdan Prodanov $^{1}$, Petya Eftimova $^{1}$, Iliyan Kotsev ${ }^{1}$ \\ and Lyubomir Dimitrov ${ }^{1}$
}

\begin{abstract}
Storms and related disasters are phenomena producing coastal hazards and endangering human life and occupation. The study evaluates coastal receptors' exposure and their vulnerability to storm-induced flooding hazard along Varna regional coast in Western Black Sea, Bulgaria. The assessment is performed employing the Coastal Risk Assessment Framework (CRAF) developed within EU FP7 RISC-KIT project. It constitutes a screening process that allows determination of susceptible alongshore sectors (hotspots) by assessing relevant hazard intensities, hazard extents and potential receptors' exposure vulnerability within them by means of coastal indices approach. The ultimate goal is to evaluate potential risk posed by flooding in support to coastal managers, decision and policy makers. Assessment of coastal receptors' exposure vulnerability is done by exposure indicators approach, using hazard intensities and flooding extents relevant to return period of 100 years. The approach consists of combining several indicators into a single index, thereby allowing a rapid comparison of coastal sectors. Five types of receptors are considered to formulate the relevant exposure indicators: Land Use, Population, Transport, Utilities and Business, which subsequently are combined into an Overall Exposure Indicator to evaluate potential direct and indirect impacts. Results show that the most vulnerable to coastal flooding in terms of exposure are coastal sectors located within Varna Bay, comprising port and industry facilities with regional, national and international significance.
\end{abstract}

Keywords: storms, coastal flooding, coastal receptors, hazard exposure, vulnerability

\section{INTRODUCTION}

Coastal areas are highly dynamic and complex multi-function systems, which include a wide number of socio-economic activities like urbanization, tourism and recreation, industrial production, port activities and shipping, agriculture etc. They are also associated with large concentration of human population, as according to the latest statistics, already $40.8 \%$ of the EU population lives within the $50 \mathrm{~km}$ coastal strip (Collet and Engelbert 2013) and it is likely that this number will increase in the future. This places growing demands on coastal resources and increases people's exposure and vulnerability to coastal hazards, like storm surge-driven floods and erosion, capable of causing human fatalities, disruption of livelihood and enormous economic loss.

Coastal flooding is a major natural hazard, regarded as among the most dangerous and harmful of natural disasters (Douben 2006). Recent climatic studies have revealed that due to increase of frequency and intensity of coastal flooding the coastal risk is likely to magnify as well (Quevauviller 2012), closely followed by possible severe impacts and consequences for population and human activities in the coastal zone. For these reasons, storm-induced flooding has recently become a topic of increased scientific and political interest. Thus, the EU Floods Directive 2007/60 identifies marine inundations and resulting negative geo-ecological and socio-economic consequences as a specific category representing major environmental threat for European coasts. Therefore, it requires Member States to assess if water sources and coastlines are subject to flood risk, to map the flood extent, assets and population at risk in vulnerable and exposed areas, in order to help coastal managers, decision and policy makers to take adequate and coordinated measures to reduce the flood risk and increase resilience to low-frequency, high impact hydro-meteorological events.

Hence, the purpose of the present study is to assess potential exposure vulnerability of several groups of receptors to storm-induced flooding hazard along Varna regional coast in Western Black Sea, Bulgaria. The study is performed employing the Coastal Risk Assessment Framework-CRAF (Ferreira et al. 2016) developed within EU FP7 project RISC-KIT (Van Dongeren et al. 2014). Briefly, this framework constitutes a screening process that allows delimitation of susceptible alongshore sectors (hotspots) by assessing relevant hazard intensities, hazard extents and potential receptors' exposure vulnerability within them. The approach results in assessment of potential risk posed by coastal flooding through calculation of coastal indices, following an existing index-based method (Gornitz 1990, McLaughlin and Cooper 2010, Ramieri et al. 2011, Balica et al. 2012). This is the only method that allow to carry out a holistic risk assessment including social, economic and environmental vulnerability and capacity. The resulting risk is relative and doesn't provide information on actual

\footnotetext{
${ }^{1}$ Coastal Zone Dynamics Department, Institute of Oceanology - Bulgarian Academy of Sciences, 40 Parvi may Blvd., Varna, 9003, Bulgaria; e-mail: n.andreeva@io-bas.bg
} 
expected losses (Van Westen 2014). Ultimately, the CRAF approach combines several hazard and exposure indicators into a single index, thereby allowing a rapid comparison of coastal sectors. Results on application of the framework and identification of 'hotspots' along Varna regional coast are presented in Valchev et al. (2016), while the present study mainly focuses on and presents results of assessment of receptors' exposure vulnerability.

Herein, under receptor we consider an entity potentially at harm (Viavattene et al. 2015). Exposure refers to "people, property, systems, or other elements present in hazard zones that are thereby subject to potential losses", while vulnerability refers to "the propensity of exposed elements such as human beings, their livelihood, and assets to suffer adverse effects when impacted by hazard events" (UNISDR 2009). Receptors taken into consideration are land use, population, transport, utilities and economic activities, as their exposure vulnerability is evaluated using exposure indicators approach (Viavattene et al. 2015). For each receptor an exposure indicator is created and evaluated, as ultimately they are combined into a single exposure index, that measure the relative exposure of different receptors within the flooded areas, thus considering vulnerability of receptors by taking into account only their presence. Evaluation of exposure is predominantly based on spatial overlay of hazard extents and different receptors' location in Geographic Information Systems (GIS) environment.

Indicator-based approach for assessment of coastal and social vulnerability to flooding on national, municipal, local and site level was extensively applied worldwide (Clark et al. 1998, Weichselgartner and Bertens 2002, Bollin and Hidajat 2006, Fernández et al. 2013, Appeaning Addo 2013). For Varna regional coast similar studies were performed by Valchev et al. (2014) and Villatoro et al. (2014).

\section{STUDY SITE}

The study site comprises the coast of Varna region located on the western Black Sea. Regional coastline, with an approximate length of about $70 \mathrm{~km}$, stretches from cape Ekrene to the north to cape St. Atanas to the south, including Varna Bay (Fig. 1).

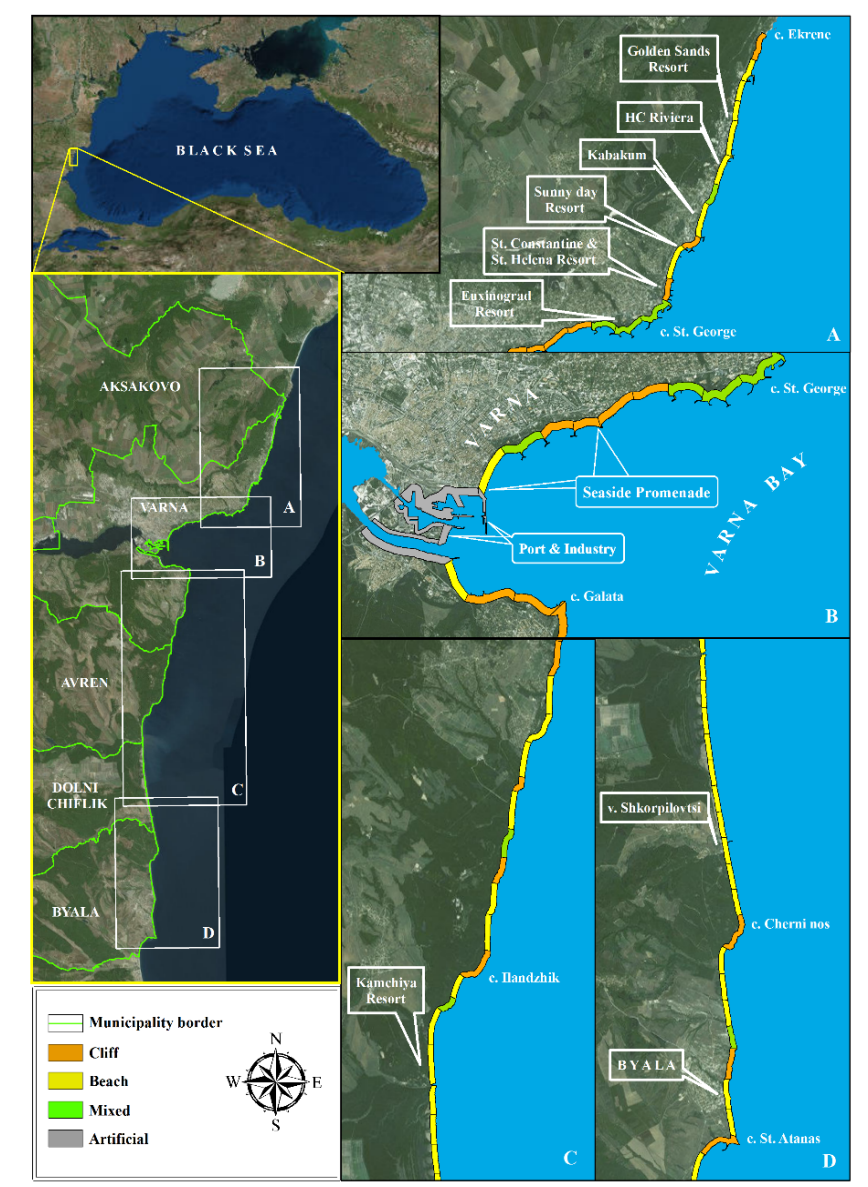

Figure 1. Schematic map of the study site indicating coast types within predefined sectors, as different coast types are shown as colored strips corresponding to each sector 
Northward, between cape Ekrene and cape St. George (Fig. 1A, B) the coast is marked by cliffs and beach bodies of different dimensions, and is predominantly occupied by several large and smaller seaside resorts with national and international importance: 'Golden sands', Holiday Club 'Riviera', 'Kabakum', 'Sunny day' Co., 'St. Constantine \& St. Helena', and 'Euxinograd'. The area also comprises villa zones mixed with family and smaller hotel complexes.

For the most part, the northern arm of Varna Bay (Fig. 1B) is protected by coastal defense structures - concrete groynes with rocky revetment in-between, which resulted in formation of several beaches. Some of these beaches are located within the city limits as the area is shaped as a seaside promenade with small beach bars and restaurants. In the most inner curve of Varna Bay lays a sandy spit - low-lying area cut by two artificial navigable canals shaping an island area called 'Ostrova' Industrial Zone. The canals connect Varna Bay to Varna Lake, which itself is linked to Beloslav Lake. This area holds the largest in Bulgaria transport and port agglomeration 'Varna-Beloslav-Devnya' industrial complex. Commercial and industry activities present along the coast in this area and directly exposed to storm surge and flooding are: Port of Varna, protected by sea wall; premises and relevant infrastructure of shipbuilding and ship-repair companies; cargo and oil terminals; cargo warehouses and oil storage tanks. Herein, one of the two main Bulgarian Navy bases - Varna Naval base is located as well.

To the south of cape Galata (Fig. 1B, C) the coast is presented by high cliffs reaching up to $125 \mathrm{~m}$. Further on, between cape Ilandzhik and cape Cherni nos (Fig. 1C, D), the longest beach (13 km) along the Bulgarian Black Sea coast - Kamchiya-Shkorpilovtsi beach - is located. It is the only beach within the study area with sandy dunes and presence of two seaside tourist complexes with regional and international importance - 'Kamchiya' and 'Long beach' (Shkorpilovtsi). In the most southern end of the site, between cape Cherni nos and cape St. Atanas (Fig. 1D), the coast consists of narrow beaches backed by high cliffs and limited by rocky capes. Additionally, to the south of cape Galata up to town of Byala the coastal area is weakly urbanized, mainly represented by villa zones, camping and bungalow sites, and holiday homes with seasonal touristic activity.

Study site coast is divided between five coastal municipalities: Aksakovo, Varna, Avren, Dolni Chiflik and Byala (Fig. 1), of which only Varna and partly Avren comprise economic activity of international importance (e.g. port and seaside resorts), while others have local or regional, mostly touristic, value.

\section{DATA AND METHODS}

\section{Hazard assessment background}

Generally, coastal flooding is caused by a combination of high water levels (storm surges plus high tides) and wave action (wave induced run-up). Since the Black Sea is considered a basin of weak tides, only superposition of storm surge and wave run-up was taken to form the total water level (TWL), which was considered as the chief property for calculation of coastal flooding hazard.

Initially, Varna regional coast was divided into 65 coastal sectors of average length $\sim 1.1 \mathrm{~km}$ according to the predominant morphological setting: 33 of sectors are mainly sandy beaches ( 8 of them are marked with sandy dune presence), 14 are cliffs of various height, and 11 are artificial (man modified), while 7 sectors are of mixed type - cliffs with adjacent small beaches (see Fig. 1). To have a reliable assessment of hazard intensities and resulting landward flood extents a high resolution Digital Elevation Model (DEM) with mean sea level as reference datum, $1 \mathrm{~m}$ horizontal and $10 \mathrm{~cm}$ vertical resolution was created.

In order to calculate hazard intensities the study followed the response approach (Garrity et al. 2006). It implies selection of a sufficiently large number of extreme storm events. This was done using available regional studies covering 57-year period (1949-2006) (Valchev et al. 2012, 2014), resulting in selection of 144 storm events, each represented by maxima of surge level, significant wave height, peak wave period, as well as mean wave direction and storm duration. These wave and water level series were used to estimate flooding hazard parameters - maximum wave run-up and total water level for each coastal sector and for each event. For calculation of wave run-up on sandy beaches, the Holman empirical model (Holman 1986) was employed, while for artificial and rocky slopes EurOtop formulation (Pullen et al. 2007). The process is described in (Eftimova et al. 2017). Subsequently, the calculated TWLs were best fitted to Generalized Extreme Value distribution (Valchev et al. 2016). Hazard intensities relevant to return periods of 20, 50 and 100 years were further analyzed since they were considered benchmark values by most of the regional stakeholders. 
The hazard extents were determined using two approaches depending on the slope of the hinterland areas, for continuously rising slopes bathtub approach was applied (Orton et al. 2014), while in case of low-laying hinterland with sandy dune presence, flood extent was calculated following (Donnelly 2008). Resultant flood extents for each coastal sector were saved as polygons in GIS environment. Receptors' exposure was estimated and its mapping was done for all considered return periods, but only results on 100 years return period are presented herein, since they are equivalent to the worst hazard conditions examined.

\section{Exposure vulnerability assessment}

In order to assess the relative exposure of different receptors to coastal flooding five types of exposure indicators were used, namely: 'Land Use', 'Population', 'Transport systems', 'Utilities' and 'Business setting' (Ferreira et al. 2016). Each of the five resultant indicators were ranked from 1 to 5: non-existent or very low (1), low (2), moderate (3), high (4) and very high (5) reflecting the degree of each receptor's exposure to flooding hazard.

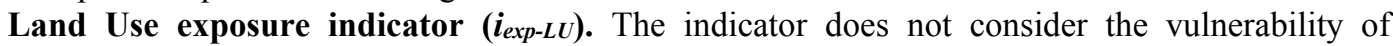
different land use classes, but only the presence of receptors. It reflects two components for each coastal sector: the exposed surface and an associated importance value for each selected land use. Calculation of $i_{\text {exp-LU }}$ within the inundated area of each coastal sector is done by the formula:

$$
i_{\text {exp }-L U}=\sum_{j=1}^{n} S_{j} * V_{j}
$$

where $n$ is number of land use classes; $S$ is surface in $m^{2}$ of each land use class; $V$ is importance (weight) value assigned to each land use class (from 1 to 10). The final output is summation of all the areas per inundated zone in a coastal sector.

For the present study Land Use data set was produced on the basis of two sources. The first source was the national CORINE Land Cover dataset version 2006 with initial scale of geo-data 1:100,000. The spatial extents of the individual polygons comprising the land use classes were refined by using very high resolution orthophoto images with ground resolution of $0.5 \mathrm{~m}$, taken in the period 20062007. The second data sources was a geo-referenced detailed spatial plan of Varna Municipality, with original scale 1:10,000 (Kotsev 2014) and land use classes according to Bulgarian Law on spatial planning (Law on special planning 2015).

Population exposure indicator (i $\left.\boldsymbol{i}_{\text {exp-POP}}\right)$. This indicator measures the relative exposure of different communities along the coast. As such, the indicator is similar to Social Vulnerability Index (SVI) proposed in Flanagan et al. (2011), which assesses the relative vulnerability of different areas to long-term health and financial recovery from an event, i.e. it considers the socio-economic characteristics of the areas exposed to certain hazards. In the present study the Social Flood Vulnerability Indicator (SFVI) (Tapsell et al. 2002) was adopted in combination with results from the project "Regional profiles - indicators of development" (Nikolova et al. 2014). This approach was preferred because it was established that exact or closely similar to SFVI indicator of social vulnerability is not yet created for Bulgaria. The SFVI for Varna regional coast was adopted following (Viavattene et al. 2015), thus creating a simple SVI. It consists of seven variables falling into five categories presented in Table 1.

\begin{tabular}{|lll|}
\hline \multicolumn{2}{|c|}{ Table 1. Categories and variables used to obtain the Social Vulnerability Indicator (SVI) } \\
\hline Category & Variables & Data used (source data: Census 2011 Bulgaria) \\
\hline $\begin{array}{l}\text { Financial } \\
\text { Deprivation }\end{array}$ & $\begin{array}{l}\text { a) Unemployment } \\
\text { b) Non-car ownership } \\
\text { c) Non-home } \\
\text { ownership }\end{array}$ & $\begin{array}{l}\text { Unemployed residents aged 16 or more } \\
\text { Households with no car/van as a percentage of all households } \\
\text { Households not owning their own home as a percentage of all } \\
\text { households }\end{array}$ \\
\hline Health & d) The long-term sick & $\begin{array}{l}\text { Residents suffering from limiting long-term illness as a } \\
\text { percentage of all residents }\end{array}$ \\
\hline Household structure & e) Single parent & $\begin{array}{l}\text { Lone parents with dependent children as a proportion of all } \\
\text { residents }\end{array}$ \\
\hline Age & f) The elderly & \begin{tabular}{l} 
Residents aged 75 and over as a percentage of all residents \\
\hline Education
\end{tabular} \\
\hline
\end{tabular}


The original four main categories were taken into account, namely: 'Financial deprivation', 'Health', 'Household structure' and 'Age'. The variable 'Non-home ownership' in the category 'Financial deprivation' was considered since according to recent ECRI report (Bouyon, 2015) more than $80 \%$ of Bulgarians has an ownership over their houses. Due to lack of data for the original variable: 'Households with more than one person per room as a percentage of all households' ('Financial deprivation' category) it was discarded from calculations and instead a new main category 'Education' was added with variable 'Residents with only primary education as percentage of all residents'. These were added due to the negative tendencies of educational level in Bulgaria observed and reported in the last 25 years (Misheva 2010, Bochukov 2012, Nikolov, 2013).

Data from 2011 Census were acquired from National Statistical Institute for each variable on the lowest available level of disaggregation - municipality. Data on variables were recalculated as percentages of the total population of each municipality, analyzed that they are not normally distributed, hence, subjected to additional transformation as in (Tapsell et al. 2002), and finally standardized as $Z$ scores. Thus processed variables were put into a general equation to calculate the SVI for each municipality (Viavattene et al. 2015):

$$
S V I=\sum_{j=1}^{n} W_{j} * C_{j}
$$

where $n$ - number of variables, $W_{j}$ is weight of each variable and $C_{j}$ - average of the variables.

Assessment of the next three indicators was done by methodologies proposed in (Viavattene et al. 2015). In essence, the methodologies regard Transport (roads and railroads) and Utilities (e.g. water, electricity, telecom and emergency services) and Business setting as systems, i.e. a set of elements (relevant systems' assets) interconnected and somehow organized to provide functions and outputs. Therein, the impacts on systems are understood to mean how the direct loss caused by a hazard (e.g. coastal flooding) propagates within the system and between its elements generating other losses beyond the hazard area, as well as delaying the recovery. So, to assess the systemic vulnerability it is necessary to collect information on spatial distribution of a given network and its nodes, outputs and inputs to define the existing interconnections related the exposed area, the uniqueness, the adaptability and the boundaries of the system to a certain degree, in order to evaluate how these relationships may either mitigate or amplify the magnitude of the initial impact. However, for the purposes of the present study only the exposure to hazard of the considered receptors, but not ripple effect of losses propagating throughout the systems is examined. For the most part, necessary data and information was collected by desktop research and field surveys, and partially by stakeholders' interaction in order to map and to value each element of the systems.

Transport systems exposure indicator $\left(i_{\text {exp-TS }}\right)$. To evaluate the indicator geo-referenced data on terrestrial transport networks location (roads and railroads) and relative importance of their assets (road class) were compiled from available map (scale 1:25,000) on railway as well as national, municipal and street network of Varna municipality and online platforms as OpenStreetMap and WorldStreetMap. To assess the exposure of transport systems within the inundated area of each coastal sector road classification of Bulgaria (Ordinance no. 2 2004) was taken into account and following the rules presented in Table 2 the exposure indicator $i_{\text {exp-TS }}$ was derived.

\begin{tabular}{|c|l|l|}
\hline \multicolumn{3}{|c|}{ Table 2. Ranking values for Transport systems exposure indicator } \\
\hline Value & Rank & Description \\
\hline $\mathbf{1}$ & $\begin{array}{l}\text { Non-existent } \\
\text { or very low }\end{array}$ & No significant transport network \\
\hline $\mathbf{2}$ & Low & Mainly local and small transport network \\
\hline $\mathbf{3}$ & Moderate & Presence of transport network with local/regional importance \\
\hline $\mathbf{4}$ & High & $\begin{array}{l}\text { High density and multiple networks (train, road, airport) of local } \\
\text { importance or regional importance }\end{array}$ \\
\hline $\mathbf{5}$ & Very high & $\begin{array}{l}\text { High density and multiple networks (train, road, airport) of } \\
\text { National or International importance }\end{array}$ \\
\hline
\end{tabular}

Utilities exposure indicator $\left(i_{\text {exp-UT }}\right)$. For each coastal sector geo-referenced data on assets location (nodes, inputs and outputs) of Utilities providing essential services, e.g. water supply network, electricity supply network and location of emergency centers, were compiled from relevant available maps (scale 1:50,000) of Varna municipality spatial planning, online platforms as OpenStreetMap and 
Wikimapia, and complemented by field surveys along the coastline, while information on assets relative importance (capacity and use) from desktop research and stakeholders' interviews. The assessment was done following the rules presented in Table 3, which led to derivation of $i_{\text {exp-UT. }}$

\begin{tabular}{|c|l|l|}
\hline \multicolumn{3}{|c|}{ Table 3. Ranking values for Utilities exposure indicator } \\
\hline Value & Rank & Description \\
\hline $\mathbf{1}$ & $\begin{array}{l}\text { Non-existent } \\
\text { or very low }\end{array}$ & No significant utilities networks/assets \\
\hline $\mathbf{2}$ & Low & Mainly local and small utilities networks/assets \\
\hline $\mathbf{3}$ & Moderate & $\begin{array}{l}\text { Presence of utilities networks/assets with local/regional } \\
\text { importance }\end{array}$ \\
\hline $\mathbf{4}$ & High & $\begin{array}{l}\text { High dense and multiple utilities networks/assets of local } \\
\text { importance or regional importance }\end{array}$ \\
\hline $\mathbf{5}$ & Very high & $\begin{array}{l}\text { high dense and multiple utilities networks/assets of national or } \\
\text { international importance }\end{array}$ \\
\hline
\end{tabular}

Business Setting exposure indicator $\left(\boldsymbol{i}_{\text {exp-BS}}\right)$. Assessment includes: (A) identification of the coastal business setting, which best describes the study site out of three options: 1) Beach frontage urban area (e.g. town) and tourist resort, 2) Port and related commercial and industrial zones and 3) Coastal harbor (with or without marina) and related urban area; (B) Identification of business assets typical for each business setting; (C) Mapping of the location of assets and collection of information on their relative importance - type, number and economic significance of businesses.

Necessary information on businesses types, number and their economic importance was acquired through desktop research and field surveys along the coast. For the mapping of assets location the following data and data sources were used: two high resolution orthophoto images with $0.5 \mathrm{~m}$ ground resolution of a) a strip along the international touristic resorts to the north of Varna - from 'Golden sands' to 'Sunny Day' Co. (image taken in 2015) and 2) Varna city coast - from groynes to Asparukhovo beach (image taken in 2007). For all other coastal areas online platforms like World Imagery and Wikimapia were used. Taking into account the gathered materials and following the rules of Table 4 the exposure indicator $i_{\text {exp-BS }}$ was obtained.

\begin{tabular}{|c|l|l|}
\hline \multicolumn{3}{|c|}{ Table 4. Ranking values for Business setting exposure indicator } \\
\hline Value & Rank & Description \\
\hline $\mathbf{1}$ & Non-existent or very low & No significant economic activities \\
\hline $\mathbf{2}$ & Low & Mainly local small economic activities \\
\hline $\mathbf{3}$ & Moderate & Local or regional economic activities \\
\hline $\mathbf{4}$ & High & Regional importance \\
\hline $\mathbf{5}$ & Very high & National or international importance \\
\hline
\end{tabular}

Overall Exposure Indicator $\left(\boldsymbol{i}_{\text {exp }}\right)$. Finally, the Overall Exposure Indicator was computed as a geometric mean of all used and tailored indicators' values (Ferreira et al. 2016):

$$
i_{\exp }=\left[\left(i_{\exp -L U} * i_{\exp -P O P} * i_{\exp -T S} * i_{\exp -U T} * i_{\exp -B S}\right)\right]^{1 / 5} .
$$

Resulting values were ranked from 1 to 5: non-existent or very low (1), low (2), medium (3), high (4) and very high (5) reflecting the degree of receptors' exposure to flooding hazard.

\section{RESULTS AND DISCUSSION}

\section{Exposure evaluation}

Land Use. To calculate the indicator the available land use classes were merged to form more common classes in order to facilitate the valuation process. For each land use class present along the coast a polygon shape file in GIS environment was created. The assignment of importance value ( 1 to 10) to each class was done focusing on the level of human occupation and activity and taking into account stakeholders preferences collected during interviews. Thus, higher scores are attributed to classes representing urban areas, industrial zones, ports and tourist resorts. The generalized land use classes and assigned importance values are presented in Table 5.

Commenting on selected categories of land use classes presented in Table 5, for the class of 'Harbors' mainly were considered big, medium and small marinas along the coast. The category of 'Ports' encompasses harbors relevant to national and international maritime transport including service 
buildings, warehouses and other assets located in the most inner part of Varna Bay. In this case the maritime transport was differentiated from 'Transport systems' relevant for this exposure indicator, as only roads and rail roads were considered in the latter. Regarding the 'Industry' category, herein businesses responsible for production and storage of goods were considered, as oppose to 'Tourist resorts' category, which mainly covers the production of recreational and other relevant services. Under 'Technical network' were included systems of buildings, structures and linear engineering networks of transport, water supply and sewage, gas and power supply, and waste treatment, located within industrial areas, which are necessary for their proper functioning. The choice of category 'Beaches' is due to beach occupation within tourist resorts and other recreational areas (attractions, beach restaurants, bars, chairs, umbrellas, etc). Sand dunes with ecological value are included in the category 'Nature conservation' since to the south of cape Galata there are sand dune complexes which are part of NATURA 2000 sites (Sundseth and Barova 2009), encompassing Special Protected Areas under the Council Directive 2009/147/EC (The Birds Directive) and Sites of Community Importance under the Council Directive 92/43/EEC (The Habitats Directive), for instance 'Galata', 'Kamchiya nature complex', 'Beach Shkorpilovtsi' and 'Kamchiyska planina'.

\begin{tabular}{|c|c|c|c|}
\hline ID code & Land use classes & Weight value & $\%$ \\
\hline 1 & Discontinuous Urban fabric & 10 & 0.23 \\
\hline 2 & Mixed functionality urban fabric & 10 & - \\
\hline 3 & Ports & 9 & 3.99 \\
\hline 4 & Tourist resorts & 9 & 6.81 \\
\hline 5 & Industry & 8 & 1.17 \\
\hline 6 & Harbours & 7 & 3.25 \\
\hline 7 & Technical networks & 7 & 1.97 \\
\hline 8 & Green urban areas & 6 & 5.07 \\
\hline 9 & Special (Military, Naval, etc.) & 5 & 3.13 \\
\hline 10 & Sport \& Leisure facilities & 4 & 0.03 \\
\hline 11 & Agriculture & 4 & 0.68 \\
\hline 12 & Nature conservation & 4 & 3.37 \\
\hline 13 & Coastal protection & 4 & 6.32 \\
\hline 14 & Beaches & 3 & 58.14 \\
\hline 15 & Forest & 2 & 5.85 \\
\hline 16 & Barren & 1 & - \\
\hline
\end{tabular}

In order to estimate the exposure indicator, initially an overlapping of GIS layers representing different land use classes and flooding polygon in each coastal sector was performed, clipping the land use surfaces outside the inundated area. Thus, taking into account the surface in $\mathrm{m}^{2}$ of different land use classes and their assigned weight values the exposure indicator was calculated by equation (1) for each coastal sector. All output values of $i_{\text {exp-LU }}$ were ranked from 1 to 5 using Maximum Breaks data classification method (Slocum 1999). Results for identified levels of hazard are shown by color mapping on Fig. 2. Each sector and its resultant level of hazard are presented as color strips, as the strip width is selected purely for visual representation purposes and does not reflect the actual flood extent. This manner of depiction was preferred due to the large scale of the study area in comparison to the scale of flooding extents in each sector. Hereafter, all visualization of results concerning the exposure indicators are displayed in the same manner.

As can be seen 'very high' ranks are attributed to 4 sectors. Two are located within the port and industry zone (Fig. 2B). Therein, such ranks are due to a combination of substantial inland flooding extent and high weight values of the land use classes affected: 'Port', 'Industry' and 'Naval'. In the case of Asparukhovo beach, land use classes like 'Tourist resort', 'Green urban areas', and 'Beaches' with diverse weight values but significant flooding extent are the reason for very high exposure. The last sector is located to the south of Kamchiya tourist complex (Fig. 2C). Herein, the 'very high' rank is relevant to low weight values of classes 'Nature conservation' and 'Beaches', but significant flood extent. High levels of exposure are defined for six coastal sectors occupied by: Euxinograd resort, Varna port, Kamchiya and Shkorpilovtsi tourist complexes (Fig. 2A, C, D), all of which represent land use classes with high weight values affected by fairly large flooding extents.

Table 5 also presents the relative proportion (\%) of all land use classes for flooding extents for return period of 100 years. It is clear that due to the direct exposure the most affected by coastal flooding is 'Beaches' land use class, although having relatively low weight value. Among the high 
weighted land use classes affected to a certain degree are 'Ports' \& 'Harbors' $(7.28 \%)$ and Tourist resorts with $5.26 \%$. Urban fabrics seems to be less vulnerable owing to their location on a higher ground or farther inland out of flooding reach.

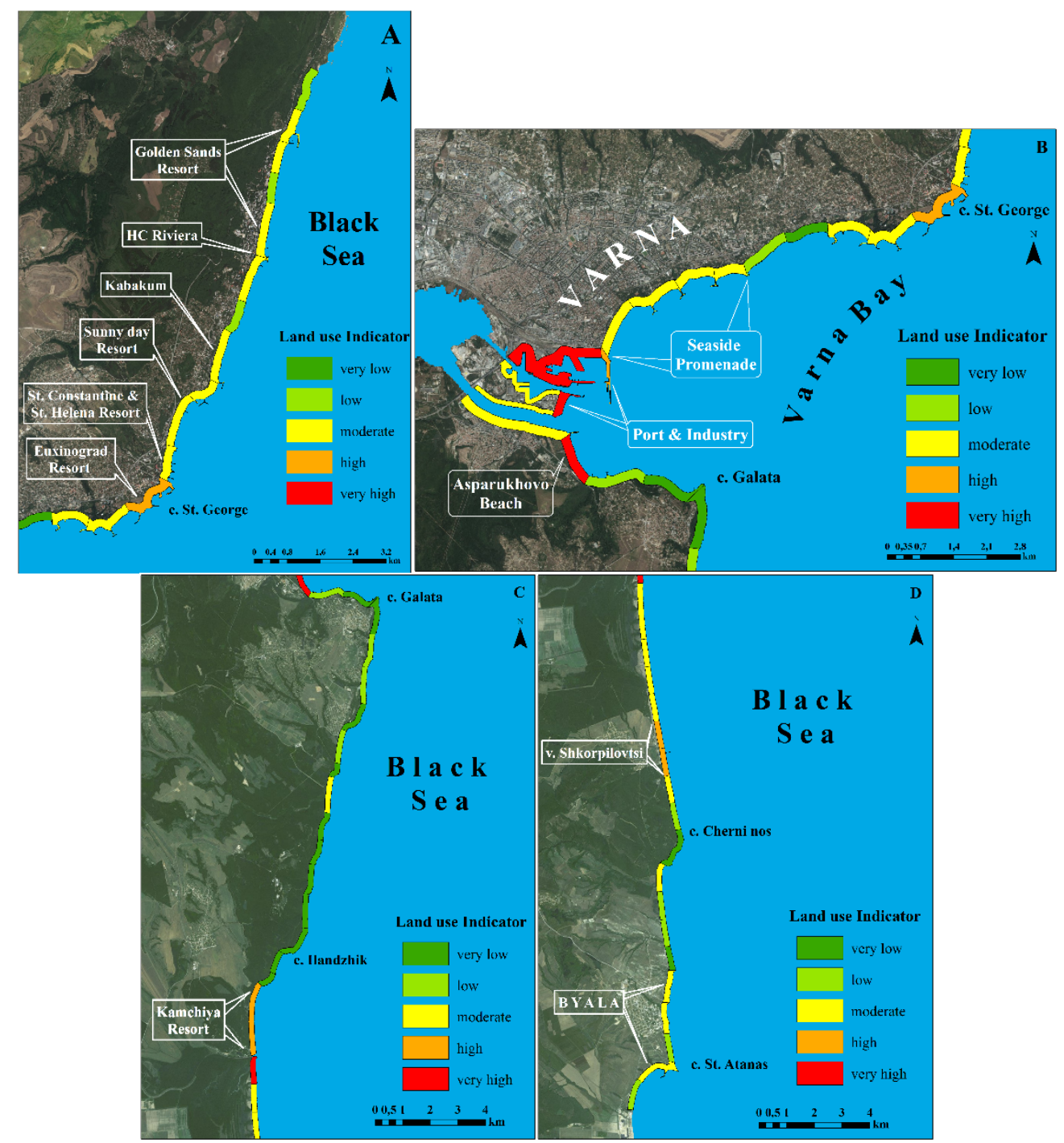

Figure 2. Land use exposure indicator $\left(i_{\text {exp-Lu}}\right)$ along Varna regional coast, return period 100 years

Population. Initially, the SVI was estimated for the five coastal municipalities comprising the study area (see Fig. 1). Then, its values were reclassified in a scale from 1 to 5 . The results showed that the most vulnerable are the municipalities of Avren and Byala having ranks of 5 and 3, respectively. The low number of initial data suggested that they were not normally distributed and despite the transformation methods applied the results lacked representativeness since calculations were not performed for all 265 municipalities in Bulgaria. Supplementary information about socio-economic development of the entire Varna district in comparison to other districts in Bulgaria was found in (Nikolova et al. 2014). This research provides a snapshot of the socio-economic conditions in Bulgarian districts as of mid-2015, as well as their development since 2000. All 28 districts are clustered into 8 types and classified from 'very good' to 'very poor' socio-economic condition. According to this report, Varna district falls into the class of 'good' socio-economic conditions. This additional information allowed for a new reclassification of the SVI values for Varna region coastal municipalities in a scale from 1 to 3: 'very low', 'low' and 'medium' with ranking intervals determined by the method of equal intervals (Fig. 3). Unfortunately, this approach does not allow assignment of a specific value for each coastal sector; therefore, a single value for all sectors within a given municipality was used. 


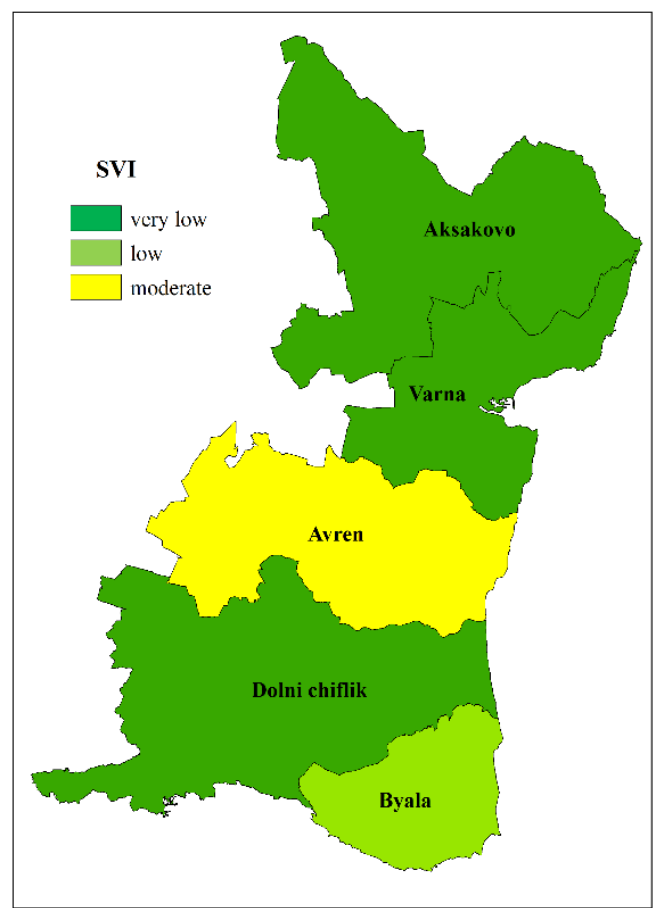

Figure 3. Social Vulnerability Indicator (SVI) for the study site

The proposed ranking suggests difficulty in claiming that the available data are representative for the exposed population along the coastline, particularly for sparsely populated coastal areas in municipalities of Aksakovo and Avren. A possible drawback in population vulnerability assessment could be ascribed to municipal scale of indicator estimation, since it does not reflect the vulnerability of inhabitants living in the vicinity of exposed areas. But given the very low density of population, if any, close to or within the affected zones this drawback has hardly biased the representativeness of the overall outcome.

Transport systems. For qualitative assessment of transport network and derivation of $i_{\text {exp-TS }}$ road classification of Bulgaria (Ordinance no. 2 2004) was taken into account and different railroad/road classes were ranked according to the rules in Table 2. Ranking values are listed in Table 6.

\begin{tabular}{|l|c|}
\hline \multicolumn{2}{|l|}{ Table 6. Ranking values for National road and railroad classes } \\
\hline Road/railroad classes & Value \\
\hline National high way and railroad & 5 \\
\hline National road, Class I, II, III & $\mathbf{4}$ \\
\hline Speed urban highway, Class I & $\mathbf{4}$ \\
\hline Urban highway, Class II & $\mathbf{3}$ \\
\hline Main street classes, Class IIla, IIIb, IV & $\mathbf{2}$ \\
\hline Municipal & $\mathbf{1}$ \\
\hline Local & $\mathbf{1}$ \\
\hline
\end{tabular}

After overlapping of GIS layers of thus ranked road/railroad network located along the regional coast and flood extent polygons a ranking value for each coastal sector according to Table 6 was assigned, evaluating what kind of road/railroad class fell within the inundated zone. Color mapping of results for transport systems exposure indicator are presented in Fig. 4.

Results' visualization shows that hazard levels for this indicator predominantly have values corresponding to 'very low' and 'low' ranks. Analysis reveals that under 'low' hazard of flooding are street classes IIIb and IV along the entire regional coast. The reason behind this is that within the regional coast from c. Ekrene to c. Galata (Fig. 4A, B) all high class roads and their assets are located either farther in the hinterland or on higher cliff-top ground, which are never affected by flooding. The same holds for the second half of the study site from c. Galata to c. St. Atanas, as additionally herein there are long stretches of coastal sectors with absence of any road systems in the coastal area (Fig. 4C, D). 


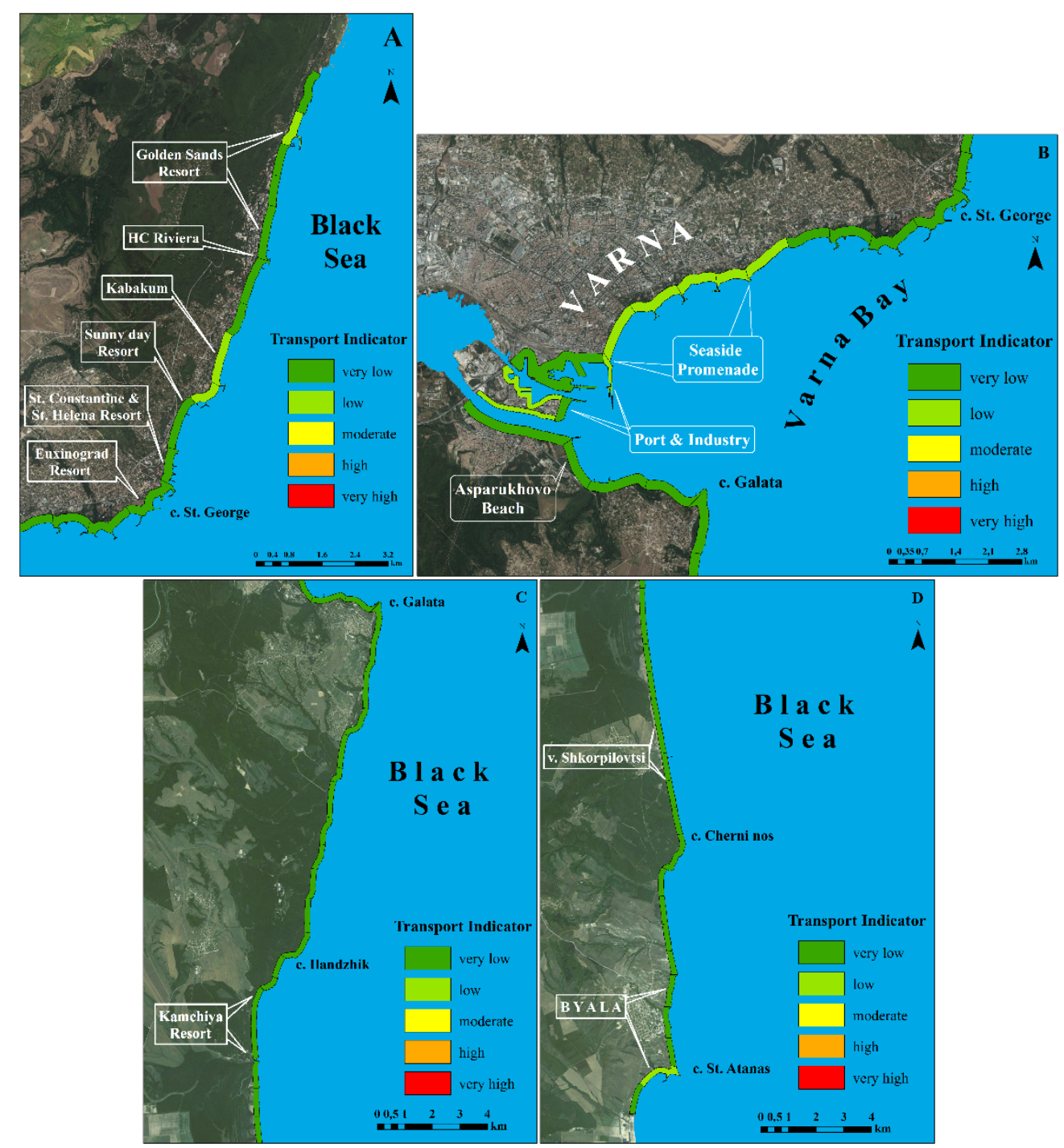

Figure 4. Transport systems exposure indicator $\left(i_{\text {exp-TS }}\right)$ along Varna regional coast, return period 100 years

Utilities. As explained previously, the geo-referenced large scale data concerning telecommunication and electricity supply networks from official available maps and online platforms were supplemented with data from several field surveys along the coast. Thus, location of minor assets like mobile phone musts and power supply substations (if any) were identified and their presence (exposure to hazard) was taken into account during ranking.

Based on expert judgment of company managing the water networks (supply and sewage systems) in Varna district none of major assets are vulnerable to coastal flooding, since the water supply and sewage pipes are deeply underground and assets like water sources or pumping stations are located far from the coastline. Nevertheless, the presence of drainage pipes for ravine waters within the beaches was considered.

As for emergency no large hospitals or medical complexes are located in the close vicinity to coastline, but field surveys localized the presence of small medical centers situated within beach domains and this also was taken into account during the ranking. Distribution of hazard levels for Utilities exposure indicator for coastal sector along Varna region is shown in Fig. 5.

Predominantly the ranking for Utilities exposure is 'very low' or 'low', since in general no major assets and/or networks were found to be under threat, i.e. within polygons of inundated zone for each sector. The only exception are sectors in the most inner part of Varna Bay (Fig. 5B), where there is a moderate concentration of Utilities services with local/regional importance due to port, production, cargo and oil storage activities, as well as the presence of Varna Naval Base. 


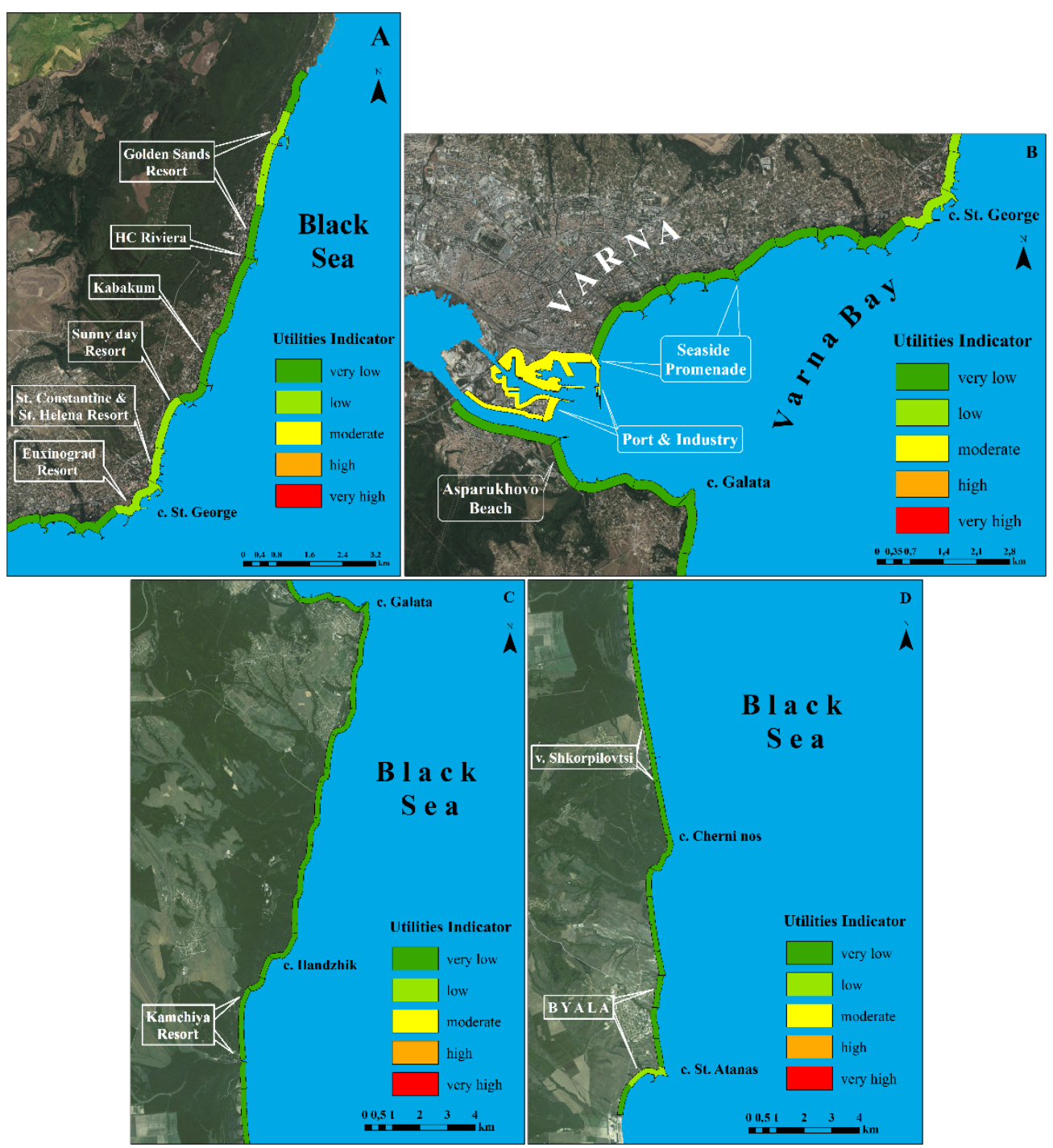

Figure 5. Utilities exposure indicator ( $i_{\text {exp-UT) }}$ along Varna regional coast, return period 100 years

Business setting. Two business settings were identified within the study site domain: 1) Beach frontage urban area (in the city of Varna) and seaside resort and 2) Port and related commercial and industrial zones. Within the first category fall the international seaside resorts 'Golden sands', Holiday Club 'Riviera', 'Kabakum', 'Sunny day' Co., 'St. Constantine \& St. Helena' and 'Euxinograd' located to the north of Varna city, and tourist complexes 'Kamchiya' and 'Long Beach' (Shkorpilovtsi) situated to the south of cape Galata. As of within the city borders the seaside promenade backed by large urban park. To the second category are attributed the industrial zone on the artificial island and the port complex situated deep into Varna Bay (see Fig. 1).

Due to the wide variety of existing coastal settings, location of different business assets and the fact that the inundation extents with few exceptions are predominantly within beach areas, the assignment of values to $i_{e x p-B S}$ within each coastal sector was done according to authors' best judgment based on the information of different businesses presence and identified significance of their economic activities, and the rules in Table 4. The color mapping is presented in Fig. 6.

As could have been expected the 'very high' levels of exposure, i.e. businesses with national and international importance, were attributed to sectors comprising international seaside resorts to the north of Varna (Fig. 6 A) and to the south of cape Galata - 'Kamchiya' tourist complex (Fig. 6C), as well as to the sectors encompassing the commercial and industry activities in the most inner part of Varna Bay (Fig. 6B). As highly exposed are considered sectors holding businesses with regional importance: in Varna Bay the seaside promenade area, at Kamchiya-Shkorpilovtsi beach and town of Byala the tourist businesses important for the economy of Avren, Dolni Chiflik and Byala municipalities. 


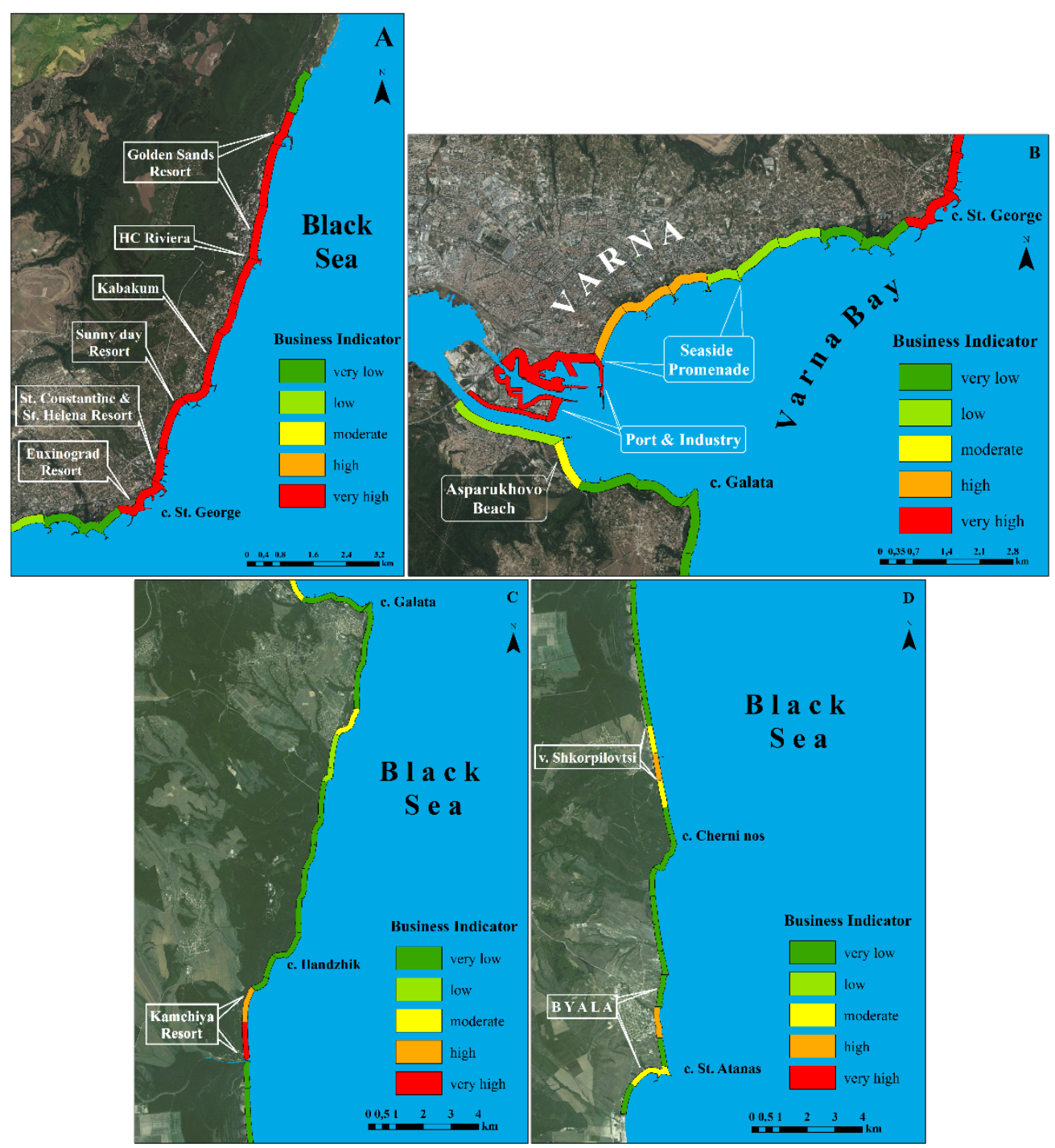

Figure 6. Business setting exposure indicator $\left(i_{\text {exp-UT }}\right)$ along Varna regional coast, return period 100 years

Overall Exposure Indicator. Finally, the ranks of all five exposure indicator were combined via equation (6) to calculate the Overall Exposure Indicator $i_{\text {exp }}$. In order to classify the resulting data values the equal ranking intervals were used (see Table 7). Color mapping for the final indicator is presented in Fig. 7.

\begin{tabular}{|c|c|c|}
\hline Rank & ervals & Ranks \\
\hline 1 & 1.4 & 1 \\
\hline 1.4 & 1.8 & 2 \\
\hline 1.8 & 2.2 & 3 \\
\hline 2.2 & 2.6 & 4 \\
\hline 2.6 & $<$ & 5 \\
\hline
\end{tabular}

Results on the Overall Exposure Indicator reveal that ranking along Varna regional coast does not exceed the value of 4 and even so only 8 sectors of 65 are ranked as 'high'. One sector is within the area of the international resort 'Golden sands' located to the north Varna city (Fig. 7A), 5 are situated within the inner curve of Varna Bay (Fig. 7B) and 2 fall within the coastal area to the south of c. Galata, comprising one coastal sector at Kamchiya resort and one sector at Byala city marina (Fig. 7C, D). Moderate exposure is detected for 6 sectors holding tourist activities (Fig. 7A), 3 sectors 
comprising the city recreational area (Fig. 7B) and 2 sectors to the south of cape Ilandzhik (Fig. 7C, D).

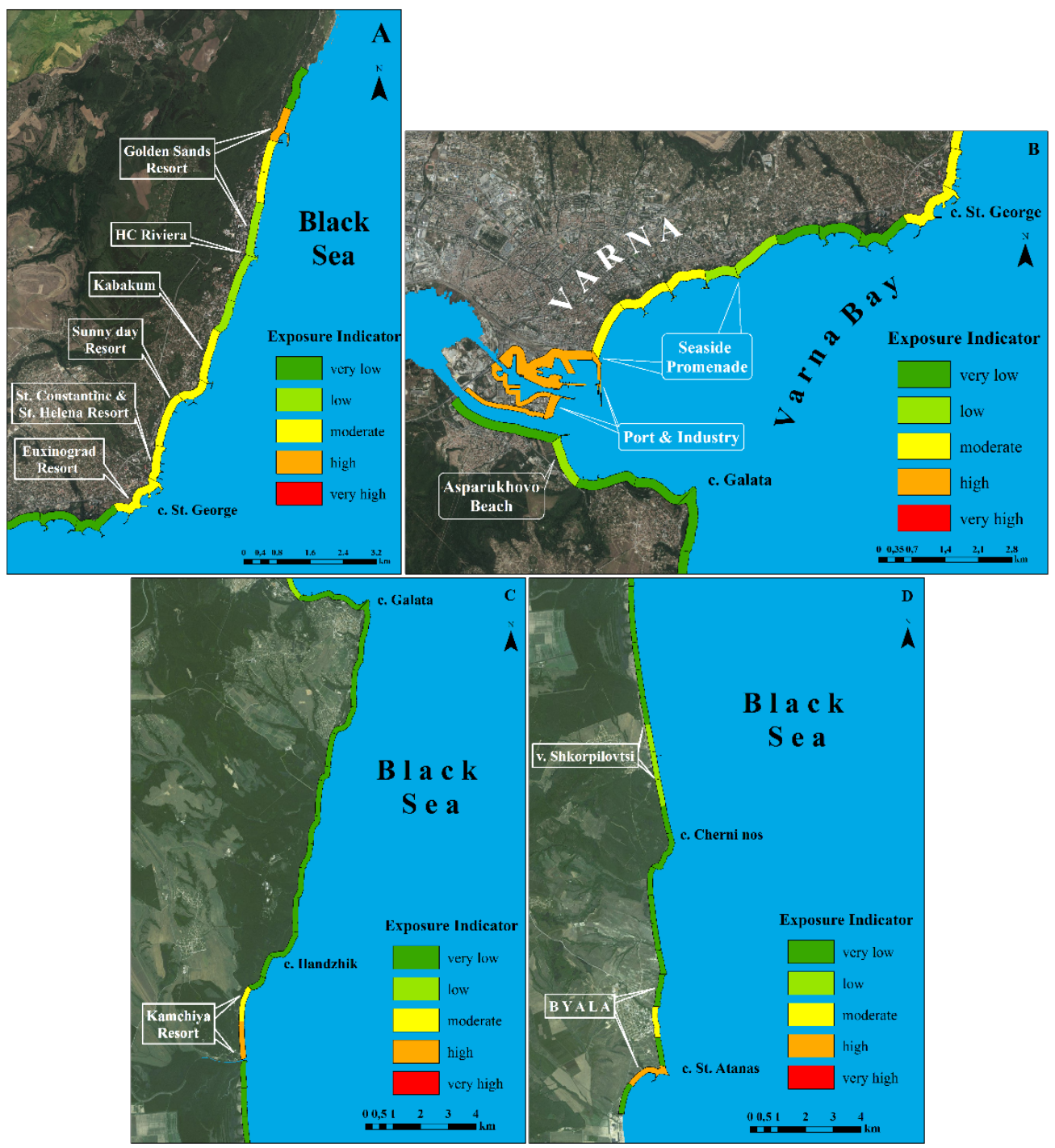

Figure 7. Overall Exposure Indicator $\left(i_{\text {exp }}\right)$ along Varna regional coast, return period 100 years

Analysis suggests that the Overall Exposure Indicator is mainly controlled by presence of different business settings and affected land use in potentially vulnerable areas. However, land use classes with significant socio-economic value, e.g. urban fabric and industry, appear to be less or not exposed to flooding hazard. The absence of coastal sectors with 'very high' rank can also be attributed to low levels of exposure of population and assets related to transport and utilities. Thus, the most vulnerable to coastal flooding in terms of exposure are coastal sectors located within Varna Bay, comprising city recreational area, port and industry facilities with regional, national and international significance and those to the north of Varna city.

\section{CONCLUSIONS}

A methodology for evaluation and analysis of receptors' exposure vulnerability to coastal flooding has been demonstrated, using Varna regional coast as a case study. It is based on indicator approach, which offers benefits for assessment of relative exposure of selected receptors: land use, population, transport systems, utilities and business settings, as individual entities and at the same time allows further examination of how exposure of particular receptors influence the overall exposure of population and socio-economic activities along Varna coast on a regional scale. Methodology was 
applied using hazard intensities and relevant flooding extents corresponding to return period of 100 years.

For population a Social vulnerability indicator, taking account of social conditions specific to Bulgaria was applied, as the highest vulnerability rank does not exceed 'moderate'. Although, it was estimated on a municipal level, presenting a possible drawback in human vulnerability assessment to coastal flooding, having in mind the very low population density close to or within the inundated areas this approach has hardly influenced the representativeness of the final results. Relative exposure of the rest of the considered receptors was evaluated by spatial overlay of flooding hazard extents and location of different land use classes, transport and utilities assets, and business settings identified along Varna regional coast. Highest exposure was defined for business activities presented by international tourist resorts, port and industry. Next in line, among the potentially affected, are land use classes, as the most vulnerable are 'Beaches' followed by 'Ports' \& 'Harbors', while Urban fabrics seems to be less exposed due to their location on cliff-top plains or farther inland. The least exposure was identified for transport and utilities networks. Logically, for the Overall Exposure Indicator it was found that it is largely influenced by presence of business settings and potentially affected land use, while the high and moderate levels of overall exposure could be attributed to population, transport and utilities vulnerability.

Presented methodology demonstrated very good ability to predict coastal receptors' exposure, as it determined that the most vulnerable to flooding are coastal sectors located within Varna Bay, comprising city recreational area, port and industry facilities with regional, national and international significance and those to the north of Varna city.

\section{ACKNOWLEDGEMENTS}

The study was developed within and funded by the European Community's $7^{\text {th }}$ Framework Program research project "Resilience-Increasing Strategies for Coasts - toolKIT" (RISC-KIT), GA no. 603458, and by the Scientific Research Fund affiliated to Ministry of Education and Science, Bulgaria, contract Д01-188.

\section{REFERENCES}

Appeaning Addo, K. 2013. Assessing Coastal Vulnerability Index to Climate Change: the Case of Accra - Ghana, Proceedings of $12^{\text {th }}$ International Coastal Symposium, Journal of Coastal Research, SI 65, 1892-1897.

Balica, S.F., N.G. Wright and F. van der Meulen. 2012. A flood vulnerability index for coastal cities and its use in assessing climate change impacts, Natural Hazards, 64(1), 73-105.

Bochukov, P. 2012. Alarming facts concerning the erudition of Bulgarians, (in Bulgarian), http://bulgarian.ruvr.ru/2012_09_24/89123267/.

Bollin, C. and R. Hidajat. 2006. Community-based disaster risk index: Pilot implementation in Indonesia. In: Birkmann, J., 2006. Measuring vulnerability to natural hazards, United Nations University Press, Tokyo, 271-289.

Bouyon, S. 2015. Recent trends in EU home ownership, ECRI Commentary No 15, 1-8, http://www.ecri.eu/new/node/410.

Clark, G., S. Moser, S. Ratick, K. Dow, W. Meyer, S. Emani, W. Jin, J. Kasperson, R. Kasperson and H. Schwartz. 1998. Assessing the vulnerability of coastal communities to extreme storms: The case of Revere, MA, USA, Mitigation and Adaptation Strategies for Global Change, 3(1), 59-82.

Collet, I. and A. Engelbert. 2013. Coastal regions: people living along the coastline, integration of NUTS 2010 and latest population grid, EUROSTAT.

Donnelly, C. 2008. Coastal Overwash: Processes and Modelling. Ph.D. Thesis, University of Lund, $53 \mathrm{p}$.

Douben, N. 2006. Characteristics of river floods and flooding: A global overview, 1985-2003, Irrigation and Drainage, 55(1), 9-21.

Eftimova, P., N. Valchev, N. Andreeva, B. Prodanov, L. Dimitrov. 2017. Calculation of maximum wave run-up and erosion at Varna regional coast (Western Black Sea) using empirical models, In: to be published in Proceedings of the $35^{\text {th }}$ International Conference on Coastal Engineering, Antalya, Turkey

Fernández, V., M. Gómez and B. Guigou. 2013. Coastal vulnerability index to global change in Uruguay, Proceedings of $11^{\text {th }}$ International Symposium for GIS and Computer Cartography for Coastal Zones Management, Victoria, British Columbia, Canada, 42-44. 
Ferreira, O., C. Viavattene, J. Jimenes, A. Bole, T. Plomaritis, S. Costas and S. Smets. 2016. CRAF Phase 1, a framework to identify coastal hotspots to storm impacts, 3rd European Conference on Flood Risk Management FLOODrisk 2016, E3S Web of Conferences 7, 10002, DOI: https://doi.org/10.1051/e3sconf/20160711008

Flanagan, B., E. Gregory, E. Hallisey, J. Heitgerd and B. Lewis. 2011. A social vulnerability index for disaster management, Journal of homeland security and emergency management, 8 (1), Article 3. (https://www.degruyter.com/view/j/jhsem.2011.8.issue1/jhsem.2011.8.1.1792/jhsem.2011.8.1.1792.xml)

Garrity, N.J., R. Battalio, P.J. Hawkes and D. Roupe. 2006. Evaluation of the event and response approaches to estimate the 100-year coastal flood for Pacific coast sheltered waters. Proceeding of the $30^{\text {th }}$ International Conference on Coastal Engineering, ASCE, 1651-1663.

Gornitz, V.M. 1990. Vulnerability of the East Coast, Journal of Coastal Research, SI 9, 201-237.

Holman, R. A. 1986. Extreme value statistics for wave run-up on a natural beach, Coastal Engineering, 9 (6), 527-544.

Kotsev, I. 2014. Structure, dynamics and regionalization of the landscape complexes in the coastal zone between Cape Kaiakra and Cape Emine. Ph.D. Thesis, Aquaprint Publ. house, Varna, 225 pp. (in Bulgarian).

Law on spatial planning. 2015. Official Gazette, 65 (In Bulgarian).

McLaughlin, S. and J.A.G. Cooper. 2010. A multi-scale coastal vulnerability index: A tool for coastal managers? Environmental Hazards, 9(3), 233-248.

Misheva, G. 2010. Bulgaria one of the last in EU on level of education, (in Bulgarian), http://dnes.dir.bg/news/bulgaria-rumania-obrazovanost-7007083.

Nikolov, A. 2013 School education in Bulgaria, Institute for Market Economics, Sofia, (in Bulgarian), http://ime.bg/var/images/secondary_education_Adrian.pdf.

Nikolova, D., A. Tsvetkov, P. Ganev, Y. Aleksiev and Z. Slavova. 2014. Regional profiles - indicators of development, Report on the project "Regional Profiles: Indicators of Development" financed by the America for Bulgaria Foundation”, 170 p., (in Bulgarian).

Ordinance No 2 for planning and design of transport and communication systems in urbanized territories. 2004, Official Gazette, 86, (in Bulgarian).

Orton, P., S. Vinogradov, A. Blumberg and N. Georgas. 2014. Hydrodynamic mapping of future coastal flood hazards for New York City, Revised final project report, Stevens Institute of Technology, $36 \mathrm{p}$.

Pullen, T., N.W.H. Allsop, T. Bruce, A. Kortenhaus, H. Schüttrumpf and J.W. van der Meer. 2007. EurOtop. Wave overtopping of sea defenses and related structures: Assessment manual, 193 p., www.overtopping-manual.com.

Quevauviller, P., D. Barceló, M. Beniston, S. Djordjevic, R. J. Harding, A. Iglesias, R. Ludwig, A. Navarra, A.N. Ortega, O. Mark, R. Roson, D. Sempere, M. Stoffel, H.A.J. van Lanen and M. Werneret. 2012. Integration of research advances in modelling and monitoring in support of WFD river basin management planning in the context of climate change, Science of the Total Environment, 440, 167-177.

Ramieri, E., A. Hartley, A. Barbanti, F. Duarte Santos, A. Gomes, M. Hilden, P. Laihonen, M. Marinova, M. Santini. 2011. Methods for assessing coastal vulnerability to climate change, ETC CCA Technical report

Slocum, T. A. 1999. Thematic cartography and Visualization. Prentice Hall Inc.

Sundseth, K., S. Barova. 2009. NATURA 2000 in the Black Sea region, EC, Environment Directorate General, Luxembourg: Office for Official Publications of the European Communities, 11 p., http://ec.europa.eu/environment/nature/info/pubs/docs/biogeos/Black\%20Sea.pdf.

Tapsell, S.M., E.C. Penning-Rowsell, S.M. Tunstall and T. Wilson. 2002. Vulnerability to flooding: health and social dimensions. Philosophical Transactions of the Royal Society of London, 360 (1796), 1511-1525, https://www.ncbi.nlm.nih.gov/pubmed/12804263.

UNISDR. 2009. Terminology on Disaster Risk Reduction. United Nations International Strategy for Disaster Reduction, Geneva, Switzerland, http://unisdr.org/eng/library/lib-terminology-eng.htm.

Valchev, N., I. Davidan, Z. Belberov, A. Palazov and N. Valcheva. 2012. Hindcasting and assessment of the western Black sea wind and wave climate, Journal of Environmental protection and ecology, 11(3), 1001-1012.

Valchev, N., N. Andreeva, P. Eftimova and E. Trifonova. 2014. Prototype of early warning system for coastal storm hazard (Bulgarian Black Sea coast), Compt. Rend. Acad. Bulg. Sci., 67 (7), 971-978. 
Valchev, N., N. Andreeva, P. Eftimova, B. Prodanov and I. Kotsev. 2016. Assessment of vulnerability to storm induced flood hazard along diverse coastline settings, 3rd European Conference on Flood Risk Management FLOODrisk 2016, E3S Web of Conferences 7 10002, DOI: 10.1051/e3sconf/20160710002.

Van Dongeren, A., P. Ciavola, C. Viavattene, S. De Kleermaeker, G. Martinez, O. Ferreira, C. Costa and R. McCall. 2014. RISC-KIT: Resilience-Increasing Strategies for Coasts - toolKIT. In: Green, A.N. and Cooper, J.A.G. (eds.), Proceedings $13^{\text {th }}$ International Coastal Symposium (Durban, South Africa), Journal of Coastal Research, SI. 70, 366-371.

Van Westen, C.J. 2014. Methodology book, Chapter 5, Subsection 5.1 Introduction to exposure, vulnerability and risk assessment, Caribbean Handbook on risk information management, CHARIM project, http://www.charim.net/methodology/51

Viavattene, C., P. Micou, D. Owen, S.J. Priest and D.J. Parker. 2015. Library of Coastal Vulnerability Indicators: Guidance Document, EU FP7 603458 research project RISC-KIT - Deliverable No: D.2.2, $136 \mathrm{p}$.

Villatoro, M., R. Silva, F.J. Méndez, B. Zanuttigh, S. Pan, E. Trifonova, I.J. Losada, C. Izaguirre, D. Simmonds, D.E. Reeve, E. Mendoza, L. Martinelli, S.M. Formentin, P. Galiatsatou and P. Eftimova. 2014. An approach to assess flooding and erosion risk for open beaches in a changing climate, Coastal Engineering, 87, 50-76.

Weichselgartner, J. and J. Bertens. 2002. Natural disaster reduction in Europe: a Don Quixotic project in the face of a changing world? In: Brebbia, C.A. (ed.) Risk Analysis III, WIP Press, Southampton, 233-242. 